\title{
Counseling Undergraduates to Embrace Entrepreneurship in South East Nigeria
}

\author{
Osorochi P. Obi \\ Department of Science Education, College of Agricultural and Science Education, \\ Michael Okpara University of Agriculture, PMB7267, Umudike, Umuahia-Nigeria
}

\section{Doi:10.5901/jesr.2013.v3n6p77}

\begin{abstract}
Changing the mindsets of undergraduates to embrace entrepreneurship through counselling might change the High graduate unemployment in Nigeria. This is a quasi-experimental study employing the Pretest Posttest Control Group Design. Using the Entrepreneurship Perception Questionnaire (EPQ), the baseline perception of 3000 undergraduates $(1500$ male, 1500 female) on entrepreneurship was obtained. 180 volunteer undergraduates with low perceptions towards entrepreneurship formed the study group. Their baseline perception was obtained. The treatment group was exposed to structured counseling program with Rationale Emotive Therapy and Cognitive Restructuring Technique at the base. The EPQ was re -administered on the study group at posttest and one month follow-up periods. Using percentage and test, the results revealed a significant gender difference only at baseline, and a significant difference between the experimental groups at both posttest and follow-up periods. It was recommended that counseling undergraduates to embrace entrepreneurship should precede entrepreneurship studies in tertiary institutions in Nigeria. Implications of the findings and limitations of the study were highlighted. Further research should focus on changing the mindset of parents and teachers as well. Those in the control group were exposed to the treatment package at the end of the study to ensure that they benefited from the program.
\end{abstract}

Keywords: Entrepreneurship, counseling, entrepreneurship education, undergraduates, Nigeria.

\section{Introduction}

The Nigerian educational system with its emphasis on traditional job-based workplace is failing her graduates entry into the rapidly changing $21^{\text {st }}$ century world-of-work. This situation is characterized by high graduate unemployment. The unemployment rate in Nigeria has risen over the years. In 1970 it was put at 4.3 percent; 1980 at 6.4 percent; 1992 at 40 percent and 2011 at 41.6 percent (Saluadeen, 2011). According to the National Bureau of Statistics (2011) unemployment rate for Nigerian youths ages 15-24 was put at 34.2 percent in 2009. Another source put the unemployment rate in Nigeria as rising from 4.9\% in 2007 to 19.7\% in 2010 (Aganga, 2010). Irrespective of the varying statistics, the unemployment rate is alarming. This was exacerbated by the current global economic meltdown which has resulted in employment becoming increasingly fluid with very high unemployment rate (IAEVG, 2010). Kumar (2010) and Babalola (2007) have proposed that the solution to the challenges in the workplace is raising a generation with new skills for future jobs and creating opportunities for jobs for themselves since neither the government nor business enterprises is prepared to do that for them.

Many nations experiencing the global economic recession have responded proactively to the global unemployment problem. U.S. government has long recognized that small businesses are the engine of the US economy providing a substantial number of employment opportunities and unlimited opportunities for potential entrepreneurs (Di Zhand and Bruning, 2011). India quickly 
integrated entrepreneurship education into their educational system (I.N.D. I.A Trust, 2009). Zhang Li and Yang Liu (2011) and Linan, Rodriguez-Cohard and Rueda-Cantuche (2011) consider entrepreneurship as key instrument to drive employment by increasing the entrepreneurial attitude of both potential and nascent entrepreneurs.

Entrepreneurship is a combination of mindsets, knowledge and skills. As mindsets are formed at the early stages of life entrepreneurship should be fostered early in life. Entrepreneurship education is designed to equip trainees with the necessary skills, knowledge, ability, interest and motivation to become entrepreneurs (Azubuike, 2006). The sole motive is to enable them to become self-employed to impact positively on sustainable development and reduce poverty. Entrepreneurship refers to an individual's ability to turn ideas into action. It includes creativity, innovation and risk taking as well as the ability to plan and manage projects in order to achieve objectives. An entrepreneur is one who is highly creative and who imagines new solutions by generating the opportunities for profit. He innovates, introduces new technologies, increases efficiency, productivity or generates new products or services.

As a result of the emphasis on entrepreneurship as the catalyst for economic development and job creation (Gibb, 1996, Minniti, 2009), many nations have developed a wide array of measures to foster entrepreneurial spirit in their systems. Key among them is the call for academic institutions such as universities to contribute to the solutions of the problem by providing appropriate educational programmes. Entrepreneurship education is designed to equip trainees with the necessary skills, knowledge, ability, interest and motivation to become entrepreneurs (Azubuike, 2006). The sole motive is to enable them to become self-employed to impact positively on sustainable development and reduce poverty.

According to I.N.D.I.A. Trust (2009) the way to success is to teach students about new sources of employment and convince them that being a business man or woman is one way of entering the labour market. A general approach would be to expose them to motivational experiences during the early stages of university life. The growing rate of unemployment makes it imperative for graduates to imbibe the spirit of entrepreneurship if they must survive and make their impact in the globalized world. Entrepreneurs bring change into the business environment with the help of technology and trained employees to maximize benefits (Sajjad, Shafi \& Dad, 2012).

Entrepreneurship education has been canvassed as an effective means of entrepreneurial learning. It has become an obvious complement to venture capital and incubators as tools to propelling economic advancement (McMullan, Chrisman \& Vesper, 2003). Daudu (2007) investigated the relevance and modalities of utilizing entrepreneurship education as a strategy for channeling the energies of youth in Nigeria away from paid employment to self-employment. He suggested the introduction of counseling for entrepreneurship to the Nigerian system of education at all levels. The basic assumption of focusing on education in order to develop entrepreneurship is based on the idea that entrepreneurial competencies are changeable and can be learned in a short period. Special entrepreneurship education became evident as the labour market got saturated and was no longer able to absorb those that graduated from the Nation's tertiary institutions. Entrepreneurship education can very well perform the important function of improving entrepreneurial and managerial skills. This is to harmonize graduate competencies with the necessities of emerging knowledge-driven economy of the $21^{\text {st }}$ century (Papayankiz, Rastelli, Damigos \& Mavrotas, 2008). Entrepreneurship education in Universities was introduced to increase the motivation and competencies of their graduates to become key persons in innovative and entrepreneurial activities (Rasmussen $\&$ Sorheim, 2009).

Wen Wu (2009) captured entrepreneurial competencies as the aggregation of all entrepreneur's essential traits including attitudes, values, beliefs, knowledge, skills, abilities, characteristics, wisdom, expertise (social, technical, managerial) and mental and behavioural tendencies. The interest in entrepreneurial competencies derives from the assumed relationship between competencies and starting a business, existence and growth of investment (Mitchelmore \& 
Rowley, 2010). Katrin, Paivi, Merle, Tonis, Natalia, Mervi, Arnis, Leena, and Urve (2011) identify such aspects of entrepreneurial competencies as knowledge and experience, motivation, capabilities and personal characteristics that enable a person to undertake and succeed in entrepreneurship. They believe that such competencies are learnable.

As a possible solution to the graduate unemployment quagmire, the National universities Commission, the regulating body for Nigerian Universities, introduced entrepreneurship education into the curriculum of Nigerian Universities as a compulsory (General studies) course for all undergraduates. The aim is to cultivate a durable culture of entrepreneurship in higher institutions of learning. Obiora (2002) considers entrepreneurship education as a viable alternative to wage employment founded on the premise that entrepreneurship is the engine that drives the economy. In spite of the value of entrepreneurship education, the impact is not yet felt among recent graduates in the country considering the high graduate unemployment in Nigeria.

The burden of this study therefore is that despite the introduction of entrepreneurship education in Nigerian universities, those who have undergone the programme do not seem to reflect the benefits of entrepreneurship education in their attitudes and perceptions towards entrepreneurship. The value of entrepreneurship education does not seem to have sufficiently impacted on them to spur them to imbibe entrepreneurial spirit and be motivated to create or wish to create their own employment after graduation.

The researcher postulates that the absence of a mandatory orientation counseling program for entrepreneurship for all undergraduates before they undergo the entrepreneurship education might be the reason for their inability to benefit from the entrepreneurship education. The current trend in the global economic landscape requires a change of mindset. There is need to influence the mindsets of the undergraduates by creating awareness on the alternative career options in the informal sector. Herr (2003), UNESCO and ILO (2002) and Bhuyan (2007) identify the vital role counseling plays in creating psychologically conducive environment that engenders and fosters entrepreneurship spirit in young ones. Daudu (2007) and Papert (1996) identify the role of counseling in creating an environment where each student will be special and utilize the opportunity to carve out a niche for himself/herself and make positive impact in the world. They suggested the introduction of counseling for entrepreneurship education into the Nigerian educational system at all levels. The purpose was to introduce counseling as a strategy for economic empowerment. The premise that underlies this study is that if counseling is provided, entrepreneurship skills can be grasped and then honed. This will bring about transformations in perceptions on entrepreneurship issues. The counselor is perceived as a vibrant, dynamic and holistic empowering change agent. Counseling is a facilitating and helping process where a professional counselor provides skills, attention and time to assist clients to explore and identify issues causing problems and provide conducive environment where change is possible. Obi, (2011) identified the counselor's role as working on students' mindsets and stimulating their interest in self-employment and business creation and emphasizing unlimited opportunities for them in the $21^{\text {st }}$ century. The counselor will utilize counseling skills and strategies garnered through training, experience and practice to proactively address the issue.

During counseling, essential skills-personal and professional will be spotlighted. Some of such skills are risks taking, openness, decency, selflessness, interpersonal communication skills and selling and promoting own products and services. Others include seeing new trends, predicting them and grabbing the opportunity. Identify gaps in existing products and services as well as networking should be stressed. Frugality, self discipline, self-confidence and engaging in life-long learning are the hallmark of entrepreneurs and should be encouraged during counseling.

The purpose of this study is to explore how counseling could influence the mindsets of undergraduates to embrace entrepreneurship after graduation. Specifically, the study sought to identify the level of perception and intention towards entrepreneurship and job creation. It will evaluate the gender differences at baseline and assess the treatment effects at both posttest and follow-up periods after counseling. One research question aimed at finding the level of perception 
of undergraduates on entrepreneurship guided the study. Four hypotheses guided the study namely:

$>$ There is no significant gender difference on entrepreneurship perception at pretest.

$>$ There is no significant difference between the entrepreneurship perception of those in the treatment of group and control at pretest.

$>$ There is no significant difference between the entrepreneurship perception of those in the treatment of group and control at posttest.

$>$ There is no significant difference between the entrepreneurship perception of those in the treatment group and control group at follow-up period.

If youths are captured and counseled to accept entrepreneurship as a viable alternative to wage employment, they will become meaningfully engaged after graduation. The economy will be stimulated positively. Poverty will reduce. The standard of living will be raised and above all violence will reduce. Then, psychology and its allied psychological sciences would have made invaluable contributions to a strong and virile economy.

\section{Method}

Participants: The Participants included a total of three thousand undergraduates (1500 male, 1500 female), mean age 23.4; SD 0.342 sampled through simple random sampling. They have all taken the entrepreneurship course in their various institutions. They completed the consent form. The study was conducted at five Universities in five states in South East Nigeria. The participants completed the Researcher generated Entrepreneurship Perception Questionnaire (EPQ). The level of their perception was thus obtained. One hundred and eighty (180) volunteer undergraduates thirty (30) from each state whose responses were low on the EPQ were enlisted into the experiment. One hundred and twenty (120) were male while sixty (60) were female. They also signed the consent form agreeing to participate in the experiment.

Instrument: The Entrepreneurship Perception Questionnaire (EPQ) was used for this study. The first section of the EPQ contained demographic details. The second section contained 20 items focusing on entrepreneurship perceptions and intentions. The EPQ was constructed by the researcher and face-validated by sending it to Counseling Psychologists and experts in Measurement and Evaluation informing them of the purpose. The reliability index for the questionnaire was 0.85 obtained after test-retest at two-week interval using Cronbach Alpha confirming its suitability. Positive attributes for entrepreneurship perception were scored 2 while negative ones were scored 1.

Treatment: This is a quasi-experimental design adopting the pretest posttest control group design. Ninety (90) males and ninety (90) females were randomly assigned to the treatment and control groups. Structured counseling program with Rational Emotive Therapy (RET) and Cognitive Restructuring technique at the base were exposed to the treatment group in group counseling sessions. The aim was to increase their awareness on the value of entrepreneurship and the need for them to embrace entrepreneurship as a viable employment and as an alternative to wage employment. This was provided in six sessions as group therapy for the treatment group. The treatment sessions involved initial establishment issues, rapport building, group cohesion, delineation of counseling goals, roles and responsibilities of clients and counselors, establishment of ground rules for group therapy, information gathering and discussions, tasks and assignments, decision-taking based on information, and termination of group activities. The control group was kept in the waiting list. The sessions were scripted and rehearsed by the research assistants (counselors) to reduce therapist factor. The EPQ was juggled and re-administered on the treatment group and control after 4-week posttest and 8-week follow-up periods. The data collected were analyzed using t test. At the end of the 8-week follow-up, those in the control group were exposed to the same treatment to ensure they benefited from the program. Percentage was used to determine their level of perception on entrepreneurship while t test was used for the hypotheses. 


\section{Results}

Table1. Percentage score for male and female on Entrepreneurship Perception

\begin{tabular}{|c|c|c|c|c|c|c|c|c|c|}
\hline & \multicolumn{4}{|c|}{ Male } & \multicolumn{4}{c|}{ Female } \\
\hline $\mathrm{N}$ & \multicolumn{2}{|c|}{ Low } & \multicolumn{2}{c|}{ High } & $\mathrm{N}$ & \multicolumn{2}{c|}{ Low } & \multicolumn{2}{c|}{ High } \\
\hline & NO. & $\%$ & NO. & $\%$ & & NO. & $\%$ & NO. & $\%$ \\
\hline 1500 & 922 & 61.47 & 578 & 38.53 & 1500 & 872 & 58.13 & 628 & 41.87 \\
\hline
\end{tabular}

Based on the survey, the result obtained from the respondents' perception on entrepreneurship revealed that 992 representing $66.47 \%$ of male was low while 578 representing $33.53 \%$ was high. This shows that more of the male respondents have low perception of entrepreneurship as a viable alternative to wage employment. A total of 872 female respondents representing $58.13 \%$ had low perception of entrepreneurship while $628(41.87 \%)$ had high perception of entrepreneurship as a viable alternative to wage employment.

Table 2. t-test calculations for mean differences for male and female at pretest.

$\begin{array}{cccccccccc}\text { Group } & \text { No. } & \text { Mean } & \text { SD } & \text { SEM } & \text { Df } & \text { t.cal. } & \text { t.crit. } & \text { Stand. Error } & \text { Decision } \\ \text { Male } & 120 & 1.18 & 0.0529 & 0.004483 & 178 & 6.9197 & 1.96 & 0.012 & \text { Do not Reject } \\ \text { Female } & 60 & 1.26 & 0.1024 & 0.013220 & & & & & \\ \text { P } \geq 0.05 & & & & & & & & \end{array}$

The $t$ test calculations reveal a statistically significant difference between male and female at pretest. The calculated t-value of 6.9197 which was greater than the critical value of 1.96 at 0.05 alpha levels indicated a statistically significant difference.

Table 3. t-test calculations for mean differences for treatment and control groups at pretest

$\begin{array}{cccccccccc}\text { Group } & \text { No. } & \text { Mean } & \text { SD } & \text { SEM } & \text { Df } & \text { t.cal. } & \text { t.crit. } & \text { Stand. error } & \text { Decision } \\ \text { Treatment } & 90 & 1.44 & 0.742 & 0.0782 & 178 & 0.5886 & 1.96 & 0.119 & \text { Reject } \\ \text { Control } & 90 & 1.37 & 0.850 & 0.0896 & & & & & \\ P \geq 0.05 & & & & & & & & & \end{array}$

The table above shows that there is no statistically significant difference between those in the treatment group and control before treatment. This is shown by the t calculated of 0.5886 which is less than the table value of 1.96 with a $\mathrm{P}$ value of 0.05 .

Table 4. t-test calculations for mean differences for treatment and control groups at posttest

$\begin{array}{cccccccccc}\text { Group } & \text { No. } & \text { Mean } & \text { SD } & \text { SEM } & \text { Df } & \text { t.cal. } & \text { t.crit. } & \text { Stand. error } & \text { Decision } \\ \text { Treatment } & 90 & 1.74 & 0.14 & 0.0148 & 178 & 24.0427 & 1.96 & 0.022 & \text { Do not Reject } \\ \text { Control } & 90 & 1.22 & 0.15 & 0.0158 & & & & & \\ \text { P } \geq 0.05 & & & & & & & & & \end{array}$

Table 4 above shows that the calculated t. value of 24.0427 is greater than the table value at $\mathrm{P}$ value of 0.05 . This shows that the result is statistically significant. This is an indication of positive treatment effect at posttest. 
Table 5. t-test calculations for mean differences for treatment and control groups at follow-up period

$\begin{array}{cccccccccc}\text { Group } & \text { No. } & \text { Mean } & \text { SD } & \text { SEM } & \text { Df } & \text { t.cal. } & \text { t.crit. } & \text { Stand. error } & \text { Decision } \\ \text { Treatment } & 90 & 1.76 & 0.0875 & 0.0092 & 178 & 27.8517 & 1.96 & 0.019 & \text { Do not Reject } \\ \text { Control } & 90 & 1.24 & 0.1540 & 0.0162 & & & & & \\ \mathrm{P} \geq 0.05 & & & & & & & & & \end{array}$

The table above shows that there was a significant difference between those in the treatment and control groups at follow-up. This is shown by the t.calculated value of 27.8517 which is greater than the table value of 1.96 at 0.05 levels of significance. The null hypothesis was thus not rejected.

\section{Discussions}

The significant gender difference observed at baseline is reflective of gender disparity in most spheres of human endeavor. Though entrepreneurship is a human universal (Minniti, 2009), the invisibility of women's entrepreneurship potentials is portrayed in literature. This might account for the entrepreneurial landscape which seems to vary between men and women. The result of the study is in line with Shinner, Giacomin and Janssen's (2012) study which found gender differences in entrepreneurial perception. For Eddleston and Powell (2012) entrepreneurship should remain a gendered process. Informal economy plays a significant role in entrepreneurship, especially as it relates to women entrepreneurs in the rural areas (Barhat $\&$ Patgoankar, 2011). Women are always at the base stimulating other economic indices. The ripple effect of women's participation in economic development should be emphasized in order to harness the benefits for entrepreneurial development.

The significant difference between the treatment group and control group at both posttest and follow-up periods is a reflection of treatment effect. It shows that the counseling provided achieved its aim of positively influencing the mindsets of undergraduates in the treatment group to embrace entrepreneurship after graduation. This confirms extant views on the matter in literature (Herr, 2003; Bhuyan, 2007; Papert, 1996; Romer-Pakkanem, 2011 and Daudu, 2007).

Though entrepreneurship education is necessary to equip youths to fit into the $21^{\text {st }}$ century world of work (INDIA Trust, 2009; Katrin et al, 2011; Papayankiz et al, 2011), it has become imperative to sensitize the students on entrepreneurship before offering them the opportunity to learn the rubrics of entrepreneurship. They have to first change their mindsets about wage employment that has been hard-wired into their psyche before accepting entrepreneurship as a viable replacement.

\section{Conclusion}

Based on the results of this study, the conclusion is drawn that counseling undergraduates to embrace entrepreneurship will contribute greatly in changing the mindset of undergraduates about entrepreneurship. Counseling undergraduates should precede the introduction of entrepreneurship studies. This will enhance and equip them to change their mindsets on entrepreneurship and enable them to benefit from the introduction of entrepreneurship studies. They will be then able to find a pathway into the $21^{\text {st }}$ century world -of-work. This paper therefore recommends among other things that counseling undergraduates should precede entrepreneurship studies in all tertiary institutions in Nigeria. There should be paradigm shift in career counseling at all levels of our educational system to reflect the new face of employment history. In addition, Governments should create conducive environments for entrepreneurship. 


\subsection{Limitations and directions for future research}

Like most studies, there are limitations to this study. The study was conducted in only five institutions in Nigeria. The study was thus limited both in scope and dept. As a human variable, outcome of group counseling may vary. Therapist factor is a major variable that may to a large extent determine the outcome of therapy. The group sessions were however scripted and rehearsed by the counselors involved. Another limitation is the small number of sample used for the study (180). This study should be replicated using larger samples and across the country. Future research in this area should focus on counseling and enlightening parents on the need for entrepreneurship, and a longitudinal study to follow-up on participants.

\subsection{Implications for counseling practice and training}

The findings of this study are particularly relevant to counseling practice and to entrepreneurship development. The findings highlight the need for counselors to be aware of their responsibilities toward creating a psychologically conducive environment for entrepreneurship development. There is need for them to increase their knowledge and skills especially in the area of career counseling to be able to provide clients with adequate career services that will satisfy clients' needs for the $21^{\text {st }}$ century world of work. The importance of advocacy for policy review in the area of entrepreneurship is evident from the findings of this study. The introduction of entrepreneurship studies into all tertiary institutions in Nigeria is a noble idea intended to reduce graduate unemployment. Such loadable objectives will hardly be achieved without changing the mindsets of the students prior to the introduction of the course. This is an important omission and should be added to policy.

\section{References}

Aganga, O. (2010). Jumpstarting jobs and productivity in an uncertain world. Paper delivered at a seminar organized by the International monetary Fund (IMF) In Washington DC USA October, 2010

Azubuike, R. N. (2006). Challenges and implications of entrepreneurial development for business education in tertiary institutions. Business Education Journa/2, 47-58.

Babalola, J. B. (2007). Reinventing Nigeria education for youth employment in competitive global economy. Distinguished lecture: University of Calabar 31 $1^{\text {st }}$ October, 2007.

Barhate, G.H. \& Patgoankar, M. (2011). Rural women entrepreneurs in the informal sector in India. International Journal of Entrepreneurial Behaviour and Research 5(3).

Bhuyan, D. (2007). Multiple Career Choices. After $(10+2)$ with Science, Arts, Commerce and Beyond. Pustak Mahal, Delhi.

Charney, A. \& Libecap, G. D. (2000). Impact of entrepreneurship education. Insights. A Kauffman Research Series. Kauffman centre for entrepreneurial learning.

Dalton, N. W. (2008). Resource management in an emerging economy: Workeracy a panacea to youth restiveness. Invited lecture Nigerian Institute of Management conference. 17-12 November, 2008.

Daudu, O. (2007). Entrepreneurship education http://www. isbe2007.org/view.php/abstract . 350

Di Zhang, D. \& Bruning, E. (2011). Personal characteristics and strategic orientation: Entrepreneurs in Canadian manufacturing companies. International Journal Entrepreneurial Behaviour Research 17(1) 82-103 Doi. $10.1108 / 13552551111107525$

Eddleston, K. A. \& Powel, G. N. (2012). Nurturing Entrepreneurs' Work-family Balance: A gendered perspective. Entrepreneurship Theory and Practice 36: 513-541 Doi.: 10.1111/j.1540-6520.2012.00506.x

Fischer, A. K., Freund, J. M. \& Crouch, J. H. (1997). Developing the entrepreneurial spirit. Journal of Entrepreneurship Education 1(1): 18-26.

Gibb, A. H. (1996). The enterprise culture and education. Understanding enterprise education and its links with small Business entrepreneurship and wider educational goals. International Small Business Management Journal 11(3).

Herr, E. L. (2003). The future of career counseling as an instrument of public policy-career counseling in the Next Decade. Career Development Quarterly, September, 2003. 
IAEVG (2010). International Association of Educational and Vocational Guidance (2010). Strategies for vocational guidance in the 2ist century. Uk.

Integrated National Development in Action Trust (I.N.D.I.A TRUST) (2009). International Journal of Educational Development 29(1): 56-64.

Katrin, A., Paivvi, k., Merle, K., Tonis, M., Natalia, N., Mervi, R., Arnis, S., Leeni, U. \& Urve, V. (2011). Creative entrepreneur's perceptions about entrepreneurial education. Creative entrepreneurship training network project. Business and Economy 10(2), 2011.

Kumar, R. (2010). G-20 Labour Ministers for faster job creation to spur recovery. IANS. Washington DC.

Linan, F., Rodriguez-Cohard, J. C. \& Rueda-Cantuche, J. M. (2011). Factors affecting entrepreneurial intention levels: A role of education. International entrepreneurship and management Journal 7(2) 195-128 Doi: 10.1007/s1365-010-0154-2.

McMullan, W. (Ed) \& Gillion, L. M. (1998). Industrial Viewpoint - Entrepreneurship Education. Technovation 18(4): 275-286

McMullan, W. E., Chrisman, J. J . \& Vesper, k. H. (2002). Lessons from successful innovations in entrepreneurial support programming. In Chrisman, J. J., Holbrook, J. A.D. \& Chua, J. H. (EDS) Innovation and Entrepreneurship in Canada: From family Business to multinationals. Calgary, Alberta. University of Calgary Press.

Mitchealmore, S. \& Rowley, J. (2010). Entrepreneurial Competencies: A literature review and development agenda. International J ournal of Entrepreneurial Behaviour and Research 16(2); 92-111

Minniti, M. (2009). Gender issues in entrepreneurship. Foundations and Trends in Entrepreneurship

5(7-8) 497-621 http://dx.doi.org/10.1561/030000021

National Bureau of Statistics (NBS) (2011).The National Mirror (Editorial) graduate unemployment: The root causes. Http://nationalmirroronline.net/editorial/2011/index/news.php.com

Obi, O. P. (2011). Paradigm shift in career counselling: Implications for entrepreneurship development. The Counsellor. A Journal of the Counselling Association of Nigeria. 29(1), 52-64.

Obiora, J. O. (2002). Empowerment opportunities in the secretarial profession. Paper presented at NAPSON Conference at FUTO, Owerri, Imo State Oct 7-11, 2002

Papayanki, L., Rastelli, I., Damigos, D., \& Mavrotas, G. (2008). Fostering entrepreneurship education in engineering curricula. In Greece Experience and challenges for a technical University. European Journal of Engineering Education 33(2) 199-210

Papert, S. (1996). The Connected family: Bridging the digital generation gap. Mariette, G. A. Longstreet Press.

Peterman, N. E. \& Kennedy, J. (2003). Enterprise education: Influencing students perceptions of entrepreneurship. Entrepreneurship, Theory and practice 23(2): 75-87

Rasmussen, E. A. \& Sorheim, R. (2006). Action-based entrepreneurship education. Technovation. 26(2): 185194

Romer-Pakkanem, J. (2011.) Get a life project - Holistic career and Entrepreneurship counselling for university students.

Sajjad, S. I., Shafi, H., Dad, A. M. (2012). Impact of culture on entrepreneur's intentions. Information Management and business Review 4(1): 30-34

Saluadeen, L. (2011). Concerns over rising unemployment in Nigeria. The nation, December $19,2011$. http://www/thenationonline.net/2011/index.php/news/30267-concerns-over-rising-unemployment.htlm

Shinnar, R. S., Giacomin, O. \& Janssen, F. (2012). Entrepreneurial perceptions and intentions: The role of gender and culture. Entrepreneurship Theory and Practice 36:485-493 Doi:10.1111/j:15406520.2012.00509.x

Stevenson, H. H. (1983). A perspective on Entrepreneurship. Harvard Business School Working Paper 9, 384131, Boston

Streeter, D. H. Jaquette, J. P. \& Hovis, K. (2002). University-wide entrepreneurship education: Alternate models and current trends. Carnell University WP. 2002

UNESCO and ILO (2002). Technical and Vocational Educational Training (TVET) for the $21^{\text {st }}$ Century. UNESCO and ILO recommendation concerning Technical and Vocational Education. UNESCO's General Conference at its $31^{\text {st }}$ session 2001.

Wen Wu, W. (2009). A competency-based model for the success of an entrepreneurial start-up. WSEAS Transaction on Business and Economics 6(6), 279-291.

Zheng Li and Yang Liu (2011). Entrepreneurship education and employment performance. An empirical study in Chinese University. Journal of Chinese Entrepreneurship 3(3): 195-203 